Copyright (C) 2013 IEEE. Personal use of this material is permitted. Permission from IEEE must be obtained for all other uses, in any current or future media, including reprinting/republishing this material for advertising or promotional purposes, creating new collective works, for resale or redistribution to servers or lists, or reuse of any copyrighted component of this work in other works. 


\title{
Use of Digital Technologies in Bridging the Gap between Face-to-Face and Remote Engineering Programs
}

\author{
Rupa Vuthaluru ${ }^{1, *}$, Euan Lindsay ${ }^{2}$, Nicoleta Maynard ${ }^{1}$, Gordon Ingram ${ }^{1}$, Moses Tadé ${ }^{1}$, Ming Ang ${ }^{1}$ and Hari \\ Vuthaluru $^{1}$ \\ ${ }^{1}$ School of Chemical and Petroleum Engineering, Curtin University, Perth, Australia \\ ${ }^{2}$ School of Engineering and Built Environment, Central Queensland University, Rockhampton, Australia \\ *Email address: r.vuthaluru@curtin.edu.au
}

\begin{abstract}
Curtin's Chemical Engineering Department has been offering distance education/online courses providing alternative educational opportunities and pathways to those who cannot physically attend university for traditional classroom activities. In particular, this mode of education is a most sought-after approach by industrial personnel, wherein non-chemical engineers can appreciate the basic unit operations and enhance their level of understanding while dealing with chemical plant operations. With the objective of closing the gap between the two modes of learning, Curtin has recently embarked on incorporating online laboratory and virtual plant exercises as part of its assessments to enhance learning outcomes. A case study is presented to show the effectiveness of online programs and their standing compared to the traditional graduate programs in terms of attainment of learning outcomes as well as assessments. More specifically this study addresses the history of distance learning, course structure and four specific areas where digital tools are applied: assessment, interactive tutorials, Internet-based experimental activities and virtual reality industrial plants for remote learning. Comparisons of students' performance in both learning formats indicate that the use of digital technologies have not only bridged the gap but also assisted in fulfilling the attainment of student learning outcomes.
\end{abstract}

Index Terms-distance education, graduate attributes, online, remote labs, virtual plants.

\section{INTRODUCTION}

Distance education (DE) has become an essential way of advancing careers in the modern world due to the ability to balance the requirements of work and professional advancement. This mode of education is a most sought-after option by industrial personnel, wherein non-chemical engineers can appreciate the basic unit operations and enhance their level of understanding while dealing with chemical plant operations. Familiarity with the principles associated with several of the unit operations in process plants can lead to a more productive environment in industry. Traditional approaches for higher education usually involve the student travelling to the physical campus of the respective institutes or universities. With the advent of Internet and other advancements in communications, a student can now receive pertinent classroom information without even being physically present at the campus. Hence, the name distance education or online, which uses a combination of audiovisual lectures, quizzes and interactive live tutorial sessions. Distance education via online access is a flexible learning environment, which provides avenues to pursue career advancement while balancing other commitments. Enrolled students can study from home or in a remote area from anywhere across the globe without having to relocate. This study can be carried out in a part-time or full-time basis. One may choose to study the entire course by distance education or can prefer to do it in mixed format (some by distance and a component face-to-face). The Garrison and Shale [1] definition of distance education offers a minimum set of criteria and allows more flexibility.

The importance of online education and the level of interest of institutions in the use of Web-based technologies to enhance the learning experience are on the rise $[2-5]$. This trend to expand instruction beyond the traditional classroom is leading universities throughout the world to develop courses or entire curricula, specifically for Web presentation [6,7]. Many authors and studies in engineering education attempted to find some research evidence for the support of Web-based instruction or the use of multimedia learning environments, and discussed the pros and cons of Web-based teaching and learning used alone or versus traditional face-to-face teaching [711]. These studies do not always result in conclusive findings on the effectiveness of Web-based technologies for improving student learning experiences. However, much of the existing research shows that there is no significant difference in student achievement using multimedia as compared to traditional instruction $[5,12]$ and most authors agree that learning is not guaranteed solely by the application of technology to informationdelivery methods; sound pedagogy is essential. Many initiatives aimed at stretching the boundaries of the traditional classroom are standalone applications with few cooperative initiatives at the local, national or international level. This leads to an insufficient transfer of know-how, and the actual integration of the Web and its related technologies to the learning experiences still depends on the individual instructor, assistant or tutor [13]. Moreover, surveys on online education indicate that it has yet to gain ground in offering basic engineering courses leading to a Baccalaureate degree in engineering $[14,15]$, likely because of the need for experiential learning. 
In a world with digital technologies within reach, it becomes of paramount importance to close the gap between the traditional learning environment and remote mode of education. With this objective in mind, the authors have assessed the value of incorporating the online laboratories to remove/close the gap so as to bring the conventional and distance education modes of learning to a similar level. The work presented in this paper is based on statistical performances of students engaged in both forms of learning environments for selected courses and the evaluation and comparison of graduate attributes achieved. Discussions are included that are based on the views collected from current industrial or mature age students on the quality and impact of these programs in fulfilling their needs at industrial workplaces through completing a survey. Also included are the merits and advantages of distance education with embedded digital technological tools as part of the learning activity for students located across the globe.

\section{Distance Education Program AT CURTIN}

\section{A. Historical Background}

The Distance Learning Program was developed by the Department of Chemical Engineering, Curtin University with sponsorship from Alcoa World Alumina Ltd. for the purpose of enhancing the knowledge base of those existing Alcoa employees who did not possess a chemical engineering background. A few purpose-based modules were developed and offered as external studies. Successful delivery of these modules lead to the further development of courses into a conversion program intended for a broader population. With the help of these online or distance education (DE) engineering courses, students can:

- Complete semester-based online courses from anywhere across the globe;

- Access course materials and assignments using Web-based tools; and

- Complete the assessments and submit their work in online mode.

In many colleges and universities [16] a transition has already been made towards blended learning, which consists of both face-to-face lecturing in the classroom along with Web-based assistance in the form of lecture material and machine-graded examinations. The distance learning program developed at Curtin University is an innovative extension to the existing blended teaching programs in Chemical Engineering, transformed to deliver materials entirely in distance mode. The advantages and disadvantages of these distance learning programs in comparison with traditional classroom courses are reviewed in this paper. In particular, the role of digital technologies, including Internet-based experimental facilities, in closing the gap between the two modes of learning are addressed in the current work.

\section{B. Rationale, Benefits and Structure of Programs}

These programs are aimed to assist the graduates achieving employment relevant to chemical and mineral processing industries, including the oil and gas industry. Some of the professionals who might benefit from the program include:

- Chemists involved in Product Analysis/Production;
- Metallurgists;

- $\quad$ Process and Plant Supervisors;

- Chemical Process Consultants;

- Quality Control Engineers;

- Trouble-shooting Teams; and

- Engineers seeking better process understanding and to practice the profession of chemical engineering in a broad spectrum of industries.

A fundamental concept in chemical engineering and in the design of chemical, mineral and petroleum processing plant is that of unit operations. Unit operations consist of the key processing steps that are combined to make up complex processes present in both manufacturing and mineral processing industries. The individual unit operations are based on identifiable scientific principles, which are translated into particular industrial applications in various processing schemes. A systematic study of the individual unit operations provides a unified and simplified background for the understanding of all processes. Unit operations make up many physical processes as well as chemical reaction systems. Therefore, the primary goal of the $\mathrm{DE}$ program is to provide a fundamental background in material and energy balances, and mass and heat transfer operations, since these are the tools used to analyse unit operations, as well as providing equipment design experience. Based on an earlier study [17] pertinent to a holistic approach to Chemical Engineering education and the demand from industry, fluid and particle mechanics, and advanced separation process units are also included as part of the programs.

Participants in the program have the opportunity to cover the details of unit operations in various segments of the program to complement or refresh their former professional training. The program provides an opportunity to break into the chemical process industry and enhance their career to practice the profession in a broad spectrum of industries. Furthermore, the distance learning mode provides the participants with a flexible learning opportunity, without compromising their current job commitments. In summary, our current programs in distance education comprise of:

- Graduate Certificate: 100 credit points;

- Postgraduate Diploma: 200 credit points, including the Design Project; and

- Master of Engineering Science: 300 credit points, including the Design Project and Thesis.

Table I shows the different units offered with their credit point values. A 25 credit unit requires about 10 hours of study per week over a 12 week semester.

\section{EFFECTIVENESS AND COMPARISON}

Large engineering classes provide an interesting perspective in relation to distance learning classes. Not only have they similarities in the lack of personal contact between teacher and student, but they are very similar in assessment methodology as well. Large engineering classes are inevitable due to the good prospects and high demand for skilled engineering employment. In view of the difficulties encountered by staff managing classes with a large number of students, online assessment is often the tool utilised by many colleges and university administrations, including Curtin. Two such units are 
TABLE I

UNITS AND CREDIT VALUES OF ONLINE PROGRAMS

\begin{tabular}{|l|c|}
\hline Name of the Unit & Credit Value \\
\hline Process Heat Transfer & 25 \\
\hline Fluid Mechanics & 25 \\
\hline Thermodynamics & 25 \\
\hline Reaction Engineering & 25 \\
\hline Process Plant Engineering & 25 \\
\hline Mass and Energy Balances & 25 \\
\hline Risk Management & 25 \\
\hline Corrosion Chemistry & 25 \\
\hline Corrosion Protection in Liquids & 25 \\
\hline Process Control and Instrumentation & 25 \\
\hline Separation Processes & 25 \\
\hline Design Project & 50 \\
\hline Research Project (Thesis) & 100 \\
\hline
\end{tabular}

compared here. They are offered both in online (distance learning) mode and on-campus traditional mode with large numbers of students. Assessment, interactive tutorials, Internet-based experimental activities and virtual reality industrial plants for remote learning are addressed in this section.

The general formats of assessments for traditional and DE units at Curtin comprise of online quizzes through web-based tools, assignments or labs, projects and a final examination. A mid-semester test in place of an assignment is also a common mode of testing in many units. The Web-based quizzes were initiated previously [17] to create an asynchronous learning environment. To make them comparable to units delivered in face-to-face traditional mode, a similar assessment pattern is followed in both modes of delivery, including final examinations. Usually, the final examinations for DE students are conducted outside Curtin, and are supervised by external people. Table II shows the assessment breakdown for online/DE units in comparison with equivalent traditional (Trad) on-campus units.

There is very little variation in terms of assessment in both modes (Table II), with the only exception being that in some units the Web-based assessment includes assignments to compensate for a mid-term test worth $7.5 \%$. All the lecture material, including iLectures (audiovisual lecture recordings), are periodically made available to both on-campus and DE students following each faceto-face lecture. The average number of students in traditional classroom units is generally around 120 to 130 although it can be as few as 30-50, whereas the average enrolment in each DE unit is around 10 students per year.

Table III shows the comparison of marks for students in the two selected units for online and traditional modes over three years. The traditionally-taught students are split into undergraduate (UG) and postgraduate (PG) coursework students, who are doing on-campus versions of Graduate Certificate, Postgraduate Diploma and Master of Engineering Science programs. For the (traditionallytaught) UG students, the average results and standard deviation (SD) from year to year are quite stable. The PG results on the other hand are more variable, both in terms of averages and standard deviation. For the same unit and year, the difference between the average results of DE and traditionally-taught PG students is usually only a few marks, but in one case there was an 18 mark difference. The average marks of the online PG students are sometimes higher and sometimes lower than those of the traditional-mode PG students. The average and SD values for the PG students are susceptible to large variations due to lower numbers in both on-campus and online modes. It is hard to draw further conclusions from a preliminary inspection of these quantitative data.

Another methodology adopted to gauge the effectiveness of these programs was to collect opinions on various aspects from currently enrolled DE students (some of these students are in the last stage of their program).

A qualitative survey with an ordinal rating scale, from 0 (ineffective) to 10 (highly effective), was used to enquire into three items:

TABLE II.

TYPES OF ASSESSMENT AND THEIR BREAKDOWN IN SELECTED UNITS

\begin{tabular}{|l|c|c|c|c|}
\hline \multicolumn{1}{|c|}{$\begin{array}{c}\text { Type of } \\
\text { Assessment }\end{array}$} & \multicolumn{2}{c|}{$\begin{array}{c}\text { Process Heat } \\
\text { Transfer }\end{array}$} & \multicolumn{2}{c|}{$\begin{array}{c}\text { Mass and } \\
\text { Energy Balances }\end{array}$} \\
\hline & DE & Trad & DE & Trad \\
\hline Quizzes & $7.5 \%$ & $15 \%$ & $7.5 \%$ & $7.5 \%$ \\
\hline Assignment/Lab & $7.5 \%$ & $15 \%$ & $7.5 \%$ & - \\
\hline Mid-semester Test & - & - & - & $7.5 \%$ \\
\hline Project & $35 \%$ & $20 \%$ & $35 \%$ & $35 \%$ \\
\hline Final Exam & $50 \%$ & $50 \%$ & $50 \%$ & $50 \%$ \\
\hline
\end{tabular}

TABLE III.

COMPARISON OF STUDENTS' PERFORMANCE IN ONLINE AND TRADITIONAL CAMPUS-BASED PROGRAMS IN SELECTED UNITS ${ }^{\text {a }}$

\begin{tabular}{|c|c|c|c|c|c|c|c|c|c|}
\hline \multirow{2}{*}{$\begin{array}{c}\text { Unit } \\
\text { Name }\end{array}$} & \multicolumn{7}{c|}{ Process Heat Transfer } \\
\hline & \multicolumn{3}{|c|}{ Year 1 } & \multicolumn{3}{c|}{ Year 2 } & \multicolumn{3}{c|}{ Year 3 } \\
\cline { 2 - 11 } & $\begin{array}{c}\text { Trad } \\
\text { UG }\end{array}$ & $\begin{array}{c}\text { Trad } \\
\text { PG }\end{array}$ & $\begin{array}{c}\text { DE } \\
(\mathrm{PG})\end{array}$ & $\begin{array}{c}\text { Trad } \\
\text { UG }\end{array}$ & $\begin{array}{c}\text { Trad } \\
\text { PG }\end{array}$ & $\begin{array}{c}\text { DE } \\
(\mathrm{PG})\end{array}$ & $\begin{array}{c}\text { Trad } \\
\text { UG }\end{array}$ & $\begin{array}{c}\text { Trad } \\
\text { PG }\end{array}$ & $\begin{array}{c}\text { DE } \\
(\mathrm{PG})\end{array}$ \\
\hline Min (\%) & 31 & 28 & 7 & 18 & 7 & 47 & 23 & 50 & 51 \\
\hline Max (\%) & 88 & 72 & 86 & 93 & 90 & 71 & 86 & 80 & 76 \\
\hline Avg (\%) & 65 & 59 & 61 & 65 & 56 & 60 & 64 & 72 & 66 \\
\hline SD (\%) & 12 & 15 & 23 & 13 & 21 & 9 & 11 & 10 & 9 \\
\hline
\end{tabular}

\begin{tabular}{|c|c|c|c|c|c|c|c|c|c|}
\hline \multirow{2}{*}{$\begin{array}{c}\text { Unit } \\
\text { Name }\end{array}$} & \multicolumn{7}{|c|}{ Mass and Energy Balances } \\
\hline & \multicolumn{3}{|c|}{ Year 1 } & \multicolumn{3}{c|}{ Year 2 } & \multicolumn{3}{c|}{ Year 3 } \\
\cline { 2 - 10 } & $\begin{array}{c}\text { Trad } \\
\text { UG }\end{array}$ & $\begin{array}{c}\text { Trad } \\
\text { PG }\end{array}$ & $\begin{array}{c}\text { DE } \\
(\mathrm{PG})\end{array}$ & $\begin{array}{c}\text { Trad } \\
\text { UG }\end{array}$ & $\begin{array}{c}\text { Trad } \\
\text { PG }\end{array}$ & $\begin{array}{c}\text { DE } \\
(\mathrm{PG})\end{array}$ & $\begin{array}{c}\text { Trad } \\
\text { UG }\end{array}$ & $\begin{array}{c}\text { Trad } \\
\text { PG }\end{array}$ & $\begin{array}{c}\text { DE } \\
(\mathrm{PG})\end{array}$ \\
\hline Min (\%) & 5 & 10 & 10 & 15 & 26 & 6 & 10 & 58 & 11 \\
\hline Max (\%) & 90 & 75 & 89 & 92 & 74 & 79 & 94 & 87 & 91 \\
\hline Avg (\%) & 68 & 55 & 58 & 64 & 54 & 57 & 65 & 77 & 59 \\
\hline SD (\%) & 15 & 18 & 25 & 14 & 13 & 22 & 14 & 10 & 23 \\
\hline
\end{tabular}


- Item 1: the usefulness of DE to ongoing workrelated tasks;

- Item 2: the effectiveness and impact of DE on their work environment; and

- Item 3: the quality of the DE programs.

Results from the survey carried out on ten DE students are shown in Fig. 1, which indicates that these programs indeed have a positive impact and assist non-chemical engineers in performing their tasks at a higher level, as evident from scores ranging from 5 to 10 . Open-ended comments received through the survey and other feedback indicate that the these programs are not only helping their employees in becoming aware of the principles associated with unit operations, but also led to a productive environment at their work sites with less wastage and optimum product yields. Examples of some open-ended comments received include:

- "My department and colleagues benefit also from my improved skills" (a senior process engineer);

- "Program will be useful for transition to refinery based job function" (a chemist);

- "I do a lot of commissioning in the process and mining industry so it helps to bridge the gap between disciplines" (a senior electrical engineer);

- "Impact on my work place ... is positive because I am able to correspond with others from different technical background in terms they are familiar with" (a senior electrical and instrument engineer);

- "I wished to enhance my skills as a researcher, by becoming more adept at scale-up and production of the materials I develop. I am located $90 \mathrm{~km}$ from the nearest university campus, and I work full time. Distance education allows me to work full time, and study in my "spare time". I find the flexibility to be essential" (a research scientist).

The final, anecdotal observation about the DE students that we would like to make is that they tend to ask different questions compared to the undergraduate students. In general, their questions tend to be deeper, less focused on marks and more on ensuring their own understanding. They also tend to ask more open-ended questions and to be more willing to try different approaches to find a solution.

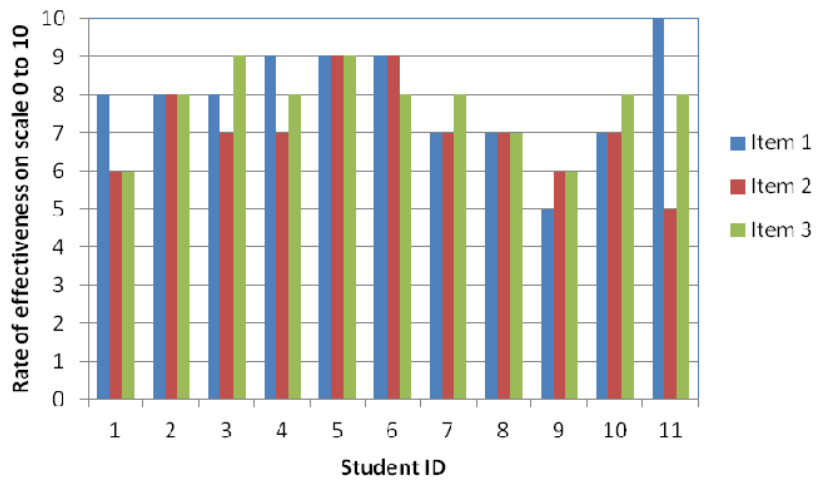

Figure 1. Survey results on the effectiveness of the DE program
In the planning and delivery of each unit, the distance education coordinators have taken into account the generic attributes expected by Engineers Australia and the Institution of Chemical Engineers (IChemE) [18]. By completing these units, students develop competencies associated with the course learning outcomes, which are aligned with Curtin's graduate attributes (Tables IV and $\mathrm{V})$. It is evident from Table $\mathrm{V}$ that the competencies achieved refer to attributes relevant to typical units in the early years of the undergraduate program. The focus of these units is primarily the understanding of basic principles and concepts, critical evaluation skills and the synthesis of information gathered, in line with CGA1 to CGA3. These three graduate attributes also satisfy the attainment of course learning outcomes $\mathrm{C} 1$ to $\mathrm{C} 3$ as shown in Table V. Achievement of these outcomes ensures that students with Chemical Engineering qualifications in any of the three related certificate programs reported earlier from Curtin University are competitive in the global workforce. The comparisons in this paper, which show student attainments in terms of course learning outcomes being similar for both traditional and distance modes, reinforce the worth of the DE programs.

\section{The CURTIN REMOTE LABORATORY AND THE VIRTUAL Plant SOFTWARE}

Engineering and science degree programs in Australia face particular challenges associated with the laboratorybased nature of these disciplines. To obtain the best learning outcomes, student learning needs to be informed by the educational use of laboratory equipment that is typically specialized, complicated, and often expensive. They often need access to this equipment for extended periods, beyond the normal timetabled class times. Particular challenges arise both with the cost of establishing and maintaining laboratories, and with ensuring appropriate access to these facilities within the context of increasingly flexible programs and complex student lives.

Interaction with real laboratory equipment and apparatus etches itself so firmly on the mind of the student that it is arguable, in the context of deeper learning, there can be no substitute [19-24].

Remote laboratories are an attractive alternative both to the logistical constraints of real physical laboratories and to the limitations of simulated laboratories. Remote laboratories provide access to the equipment within a physical laboratory through a Web interface, allowing students to utilise the equipment to undertake experiments without being physically present in the laboratory. The remote access can involve a range of interfaces from very simple text data through to complex controls, live video and audio feeds, and support for student collaboration.

Engineers Australia (EA) is responsible for assessing the competency of engineers throughout Australia, with the required graduate skills referred to as the Stage One Competencies. The effect of remote laboratories on stage one competencies and advantages over traditional laboratories has been analysed earlier [20], indicating the positive outcomes of programs that include remote laboratories that are designed to embody the guiding pedagogical principles. 
TABLE IV.

EXPECTED GRADUATE ATTRIBUTES AND LEARNING OUTCOMES ${ }^{\text {a }}$

\begin{tabular}{|c|c|c|}
\hline $\begin{array}{l}\text { Institution of } \\
\text { Chemical } \\
\text { Engineers [18] }\end{array}$ & $\begin{array}{l}\text { Curtin University } \\
\text { Graduate Attributes }\end{array}$ & $\begin{array}{l}\text { Course Learning } \\
\text { Outcomes }\end{array}$ \\
\hline $\begin{array}{l}\text { IChE1 } \\
\text { Mathematics and } \\
\text { underpinning } \\
\text { sciences }\end{array}$ & $\begin{array}{l}\text { CGA1 } \\
\text { Apply discipline } \\
\text { knowledge, } \\
\text { principles and } \\
\text { concepts }\end{array}$ & $\begin{array}{l}\text { C1 } \\
\text { Apply scientific and } \\
\text { engineering principles } \\
\text { to process engineering } \\
\text { design and } \\
\text { development, } \\
\text { including sound risk } \\
\text { management, } \\
\text { environmental and } \\
\text { OHS practice }\end{array}$ \\
\hline $\begin{array}{l}\text { IChE2 } \\
\text { Core chemical } \\
\text { engineering } \\
\text { (including core } \\
\text { process safety) } \\
\end{array}$ & $\begin{array}{l}\text { CGA2 } \\
\text { Think critically, } \\
\text { creatively and } \\
\text { reflectively }\end{array}$ & $\begin{array}{l}\text { C2 } \\
\text { Think critically and } \\
\text { creatively to generate } \\
\text { innovative and } \\
\text { optimum solutions }\end{array}$ \\
\hline \multirow[t]{2}{*}{$\begin{array}{l}\text { IChE3 } \\
\text { Engineering } \\
\text { practice and } \\
\text { advanced } \\
\text { engineering } \\
\text { practice }\end{array}$} & $\begin{array}{l}\text { CGA3 } \\
\text { Access, evaluate } \\
\text { and synthesize } \\
\text { information }\end{array}$ & $\begin{array}{l}\text { C3 } \\
\text { Identify, evaluate and } \\
\text { synthesize information } \\
\text { from a range of } \\
\text { sources to optimize } \\
\text { process engineering } \\
\text { design and } \\
\text { development }\end{array}$ \\
\hline & $\begin{array}{l}\text { CGA4 } \\
\text { Communicate } \\
\text { effectively }\end{array}$ & $\begin{array}{l}\text { C4 } \\
\text { Communicate } \\
\text { effectively in ways } \\
\text { appropriate to the } \\
\text { discipline, audience } \\
\text { and purpose }\end{array}$ \\
\hline \multirow[t]{2}{*}{$\begin{array}{l}\text { IChE4 } \\
\text { Design practice } \\
\text { and advanced } \\
\text { design practice }\end{array}$} & $\begin{array}{l}\text { CGA5 } \\
\text { Use technologies } \\
\text { appropriately }\end{array}$ & $\begin{array}{l}\text { C5 } \\
\text { Use appropriate } \\
\text { information and } \\
\text { process technologies } \\
\text { (recognizing their } \\
\text { advantages and } \\
\text { limitations) in the } \\
\text { design and } \\
\text { development of } \\
\text { sustainable process } \\
\text { systems }\end{array}$ \\
\hline & $\begin{array}{l}\text { CGA6 } \\
\text { Utilise lifelong } \\
\text { learning skills }\end{array}$ & $\begin{array}{l}\text { C6 } \\
\text { Engage in continuous } \\
\text { education, training and } \\
\text { research, and take } \\
\text { control of their own } \\
\text { learning and } \\
\text { development }\end{array}$ \\
\hline $\begin{array}{l}\text { IChE5 } \\
\text { Essential em- } \\
\text { bedded Learning } \\
\text { (Sustainability, } \\
\text { SHE, ethics) } \\
\end{array}$ & $\begin{array}{l}\text { CGA7 } \\
\text { International } \\
\text { perspective }\end{array}$ & $\begin{array}{l}\text { C7 } \\
\text { Recognize and apply } \\
\text { international standards } \\
\text { and best practice in } \\
\text { process engineering }\end{array}$ \\
\hline $\begin{array}{l}\text { IChE6 } \\
\text { Essential em- } \\
\text { bedded learning } \\
\text { (Transferable } \\
\text { skills) }\end{array}$ & $\begin{array}{l}\text { CGA8 } \\
\text { Cultural } \\
\text { understanding }\end{array}$ & $\begin{array}{l}\text { C8 } \\
\text { Demonstrate respect } \\
\text { for cultural diversity }\end{array}$ \\
\hline $\begin{array}{l}\text { IChE7 } \\
\text { Advanced } \\
\text { chemical } \\
\text { engineering } \\
\text { (Depth, Breadth) }\end{array}$ & $\begin{array}{l}\text { CGA9 } \\
\text { Apply professional } \\
\text { skills }\end{array}$ & $\begin{array}{l}\text { C9 } \\
\text { Be 'career ready' for } \\
\text { the process } \\
\text { engineering profession, } \\
\text { demonstrate leadership } \\
\text { qualities, and work } \\
\text { ethically and } \\
\text { professionally both } \\
\text { within a team and } \\
\text { independently }\end{array}$ \\
\hline
\end{tabular}

${ }^{\mathrm{a}}$ The attributes in each row are not equivalent; e.g. IChE2 $\neq$ CGA2
TABLE V.

COMPETENCIES ACHIEVED IN TRADITIONAL AND ONLINE EQUIVALENT UNITS IN TERMS OF GRADUATE ATTRIBUTES

\begin{tabular}{|c|c|c|c|c|}
\hline $\begin{array}{c}\text { Online } \\
\text { Assessment }\end{array}$ & $\begin{array}{c}\text { Traditional } \\
\text { Assessment }\end{array}$ & $\begin{array}{c}\text { \% of } \\
\text { Total } \\
\text { Marks }\end{array}$ & $\begin{array}{c}\text { IChemE } \\
\text { Attributes }\end{array}$ & $\begin{array}{c}\text { Course } \\
\text { Learning } \\
\text { Outcomes }\end{array}$ \\
\hline $\begin{array}{c}\text { Web-based } \\
\text { quizzes }\end{array}$ & $\begin{array}{c}\text { Web-based } \\
\text { quizzes }\end{array}$ & 7.5 & IChE1,2,3 & $\mathrm{C} 1, \mathrm{C} 2, \mathrm{C} 3$ \\
\hline $\begin{array}{c}\text { Project / lab } \\
\text { report }\end{array}$ & $\begin{array}{c}\text { Project / lab } \\
\text { report }\end{array}$ & 35 & $\mathrm{IChE1,2,3}$ & $\mathrm{C} 1, \mathrm{C} 2, \mathrm{C} 3$ \\
\hline $\begin{array}{c}\text { Assignment } \\
\text { Mid- } \\
\text { semester test }\end{array}$ & 7.5 & $\mathrm{IChE1,2}$ & $\mathrm{C} 1, \mathrm{C} 2$ \\
\hline $\begin{array}{c}\text { Final } \\
\text { examination }\end{array}$ & $\begin{array}{c}\text { Final } \\
\text { examination }\end{array}$ & 50 & $\mathrm{IChE} 1,2$ & $\mathrm{C} 1, \mathrm{C} 2$ \\
\hline
\end{tabular}

The on-line laboratory paradigm is based on a multiplatform client-server design, where personal computers cooperate by sharing information over the Internet and by accessing a laboratory facility that houses the experimental equipment. The focus of previous work has been on monitoring industrial facilities in real-time and on gathering data to be used later for educational purposes. This defines a one-way mode of interaction with the physical process. The approach presented in our work permits a two-way interaction because the students can effect real actuations on the system in addition to monitoring the effects of such commands. The didactic environment is based on a distributed architecture featuring two distinct parts, namely (i) an on-site server and (ii) one or more remote clients. The on-site server is a computer located near the physical process. It is equipped with a hardware interface designed to communicate with the sensors that capture measurements from the process, and with the actuators that implement actions on the process. A video camera and a microphone are available as additional sensors to provide visual and aural sensory perception. The server software receives commands issued by the client over the Internet, and transmits them to the physical process. The server is also responsible for returning to the client the value of the variables that define the state of the physical process, including a video image.

Keeping in mind the need for additional resources that provide practical experience using digital technologies, as well as the need to bridge the gap between face-to-face and remote learning modes, Curtin Engineering has developed a distributed laboratory to enhance the pedagogical content of on-line courses pertinent to the topic of Fluid Mechanics. Although initially conceived for use in mechatronics and chemical engineering fields, the infrastructure is sufficiently general to serve as a paradigm for use across the engineering disciplines.

By removing the requirement for co-locating the students and the hardware, online laboratories are able to realise numerous benefits, including: (i) student access at any time of the day to the equipment needed to complete a laboratory assignment or exercise, rather than access during a single timetabled class; (ii) the convenience of being able to complete laboratory work from home, a library, or anywhere else that an Internet connection is offered; and (iii) due to the secured nature of the laboratories, minimising equipment attrition through loss or misuse, thereby reducing the cost of maintenance compared to a proximal laboratory. 


\section{A. Online Laboratory Task}

An online experiment was designed as part of an undergraduate / postgraduate program for fluid mechanics students to study and visualize flow in pipes, not only in the laminar and turbulent regimes, but also in the transitional flow regime. The main objectives for this task were to:

- Identify typical values of the Reynolds Number for the laminar, transitional and turbulent regimes of flow in a pipe with a circular crosssection;

- Understand the frictional resistance concept applied in pipe flow and obtain the friction factor for a range of different flows; and

- Demonstrate abilities in data-collection, analysis and interpretation of experimental results.

\section{B. Experimental Set-up}

The physical setup of this rig involves pumping oil in one end of a 2 metre long pipe where friction loss can be measured as a function of the flow rate. The Reynolds Number at flow transitions can also be determined through inspection of the velocity profile. The rig uses various sensors to determine flow, pressure and friction at several points along the pipe, as well as using sophisticated particle image velocimetry (PIV) cameras to show the flow profile within the pipe. Fig. 2 shows the arrangement in which fluid from a supply tank is pumped through a straight pipe, along which the frictional loss will be measured. The rate of flow in the pipe is measured by the sophisticated PIV camera.

The rig is controlled via a Graphical User Interface application (Fig. 3). The two controllable elements of the rig are the pump (ON/OFF) and the control valve position. Measurement elements include ten pressure sensors, a flow rate sensor, both oil and ambient temperatures and a valve position signal.

\section{Virtual Plant Exercise}

Another approach to addressing issues of remote access has been the increasing popularity and utilisation of simulations. Instead of interacting with a real physical system, students interact with a simulated model of reality.

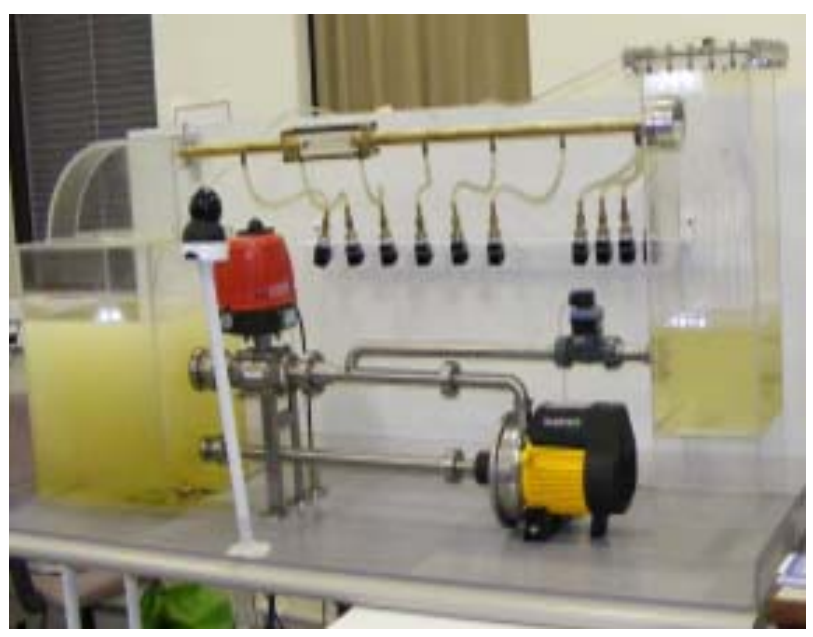

Figure 2. Remote laboratory equipment for the study of the flow through a pipe

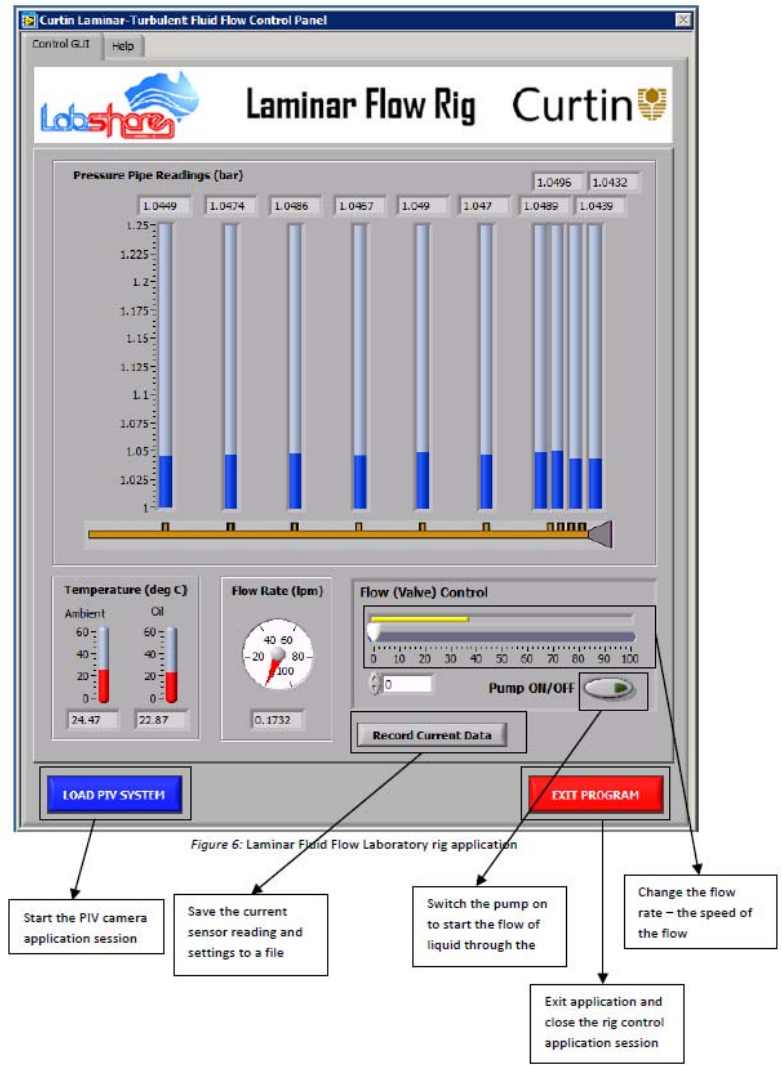

Figure 3. User interface for the remote pipe flow experiment: clicking on the Launch button in the Rig Control window will start up the control panel shown

The benefits of this approach include self-directed learning and a positive impact on intrinsic learner motivation, high student engagement using a novel context-appropriate learning and performance assessment tool, and good achievement of planned learning outcomes and objectives [24-26].

Virtual Reality (VR) is a rapidly-growing technology that utilises the increased power of computers to simulate real or imaginary environments and situations with a high degree of realism and interactivity. It is an emerging technology with potential applications in areas such as product design and modeling, process simulation, planning, testing and verification, real-time shop-floor controls, training and maintenance.

The specific design approach applied in constructing the prototype VR system of an oil refinery used in this study, as well as the activities embedded in the system can be found elsewhere $[25,26]$. The learning environment is based around spherical imagery of a real operating plant coupled with interactive embedded activities and content. The VR learning tool was developed by applying aspects of relevant educational theory and proven instructive teaching approaches.

The immersive and interactive VR learning environment tool has been successfully deployed to achieve learning outcomes and objectives of a chemical engineering unit (Process Heat Transfer). The projectoriented assessment offered to the student is based around two real heat exchangers located at BP's Brisbane refinery. It involves the exploration of the refinery and the analysis of plant operating data using the Virtual Process 
Plant software (Fig. 4). Students are provided with necessary information prior to undertaking the project tasks and are instructed in a step-by-step manner to help them become familiarised with the software. Students went through various items required as part of the project either in group $(\mathrm{G})$ format or individually (I) to complete the report sections outlined in Table VI.

\section{ASSESSMENT, OUTCOMES AND COMPARISONS}

Following the introduction of online experiments and virtual plant exercises for the selected units, namely Fluid Mechanics and Process Heat Transfer, students enrolled in online programs were able to achieve the respective graduate attributes in these units. These assessments also enabled them to bridge the gap between conventional and distance modes of learning. While the learning environments were different, including the total enrolled student numbers (typically over 100 in on-campus units, as opposed to around 10 in online units), the average marks attained by the online PG students are similar to their traditionally-taught PG counterparts, as indicated in earlier sections.

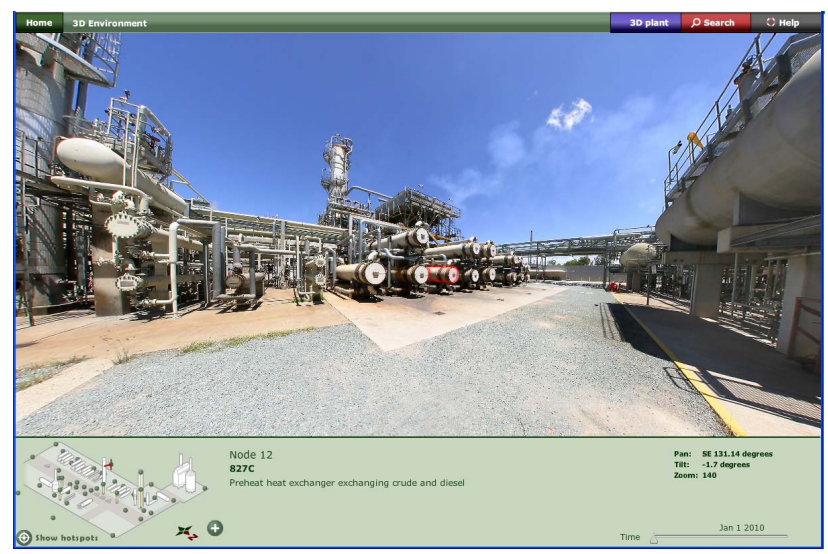

Figure 4. View of heat exchangers in the Virtual Process Plant

TABLE VI.

SUMMARY OF PROCESS HEAT TRANSFER REPORT SECTIONS AND ASSESSMENT FOR THE VIRTUAL PLANT EXERCISE

\begin{tabular}{|l|c|l|l|}
\hline Report Section & Type & $\begin{array}{l}\text { Length } \\
\text { (pages) }\end{array}$ & $\%$ Marks \\
\hline Executive summary & $\mathrm{G}$ & 0.5 & 5 \\
\hline Introduction & $\mathrm{G}$ & $1-2$ & 5 \\
\hline $\begin{array}{l}\text { Unit, stream and data } \\
\text { identification }\end{array}$ & $\mathrm{G}$ & 1 & 5 \\
\hline $\begin{array}{l}\text { Calculation of heat transfer } \\
\text { duty }\end{array}$ & $\mathrm{G}$ & $2-4$ & 10 \\
\hline $\begin{array}{l}\text { Calculation of overall heat } \\
\text { transfer coefficient }\end{array}$ & $\mathrm{G}$ & $2-5$ & 15 \\
\hline $\begin{array}{l}\text { Report quality for common } \\
\text { section }\end{array}$ & $\mathrm{G}$ & - & 5 \\
\hline Calculation of fouling factor & $\mathrm{I}$ & $2-4$ & 20 \\
\hline $\begin{array}{l}\text { Prediction of fouling on outlet } \\
\text { temperatures }\end{array}$ & $\mathrm{I}$ & $3-5$ & 30 \\
\hline $\begin{array}{l}\text { Report quality for individual } \\
\text { section }\end{array}$ & $\mathrm{I}$ & - & 5 \\
\hline $\begin{array}{l}\text { Extension study for } \\
\text { postgraduate students }\end{array}$ & $\mathrm{I}$ & $2-4$ & Extra 10 \\
\hline Completed questionnaires & $\mathrm{I}$ & - & Required \\
\hline
\end{tabular}

Additionally, the graduate learning outcomes of online students in these units, as outlined in Table IV, were comparable to undergraduate programs, in particular the attainment of CGA1, CGA3 and CGA5 via the introduction of online experiments and virtual plant exercises. All three graduate attributes also satisfy the attainment of course learning outcomes $\mathrm{C} 1$ to $\mathrm{C} 3$ as shown in Table V. This suggests that the introduction of additional components, such as online lab exercises and virtual plant tours, not only reduced the gap, but also enabled the programs to be in line with the traditional mode of education without losing any of the essential graduate attributes required as part of a student's learning process.

\section{CONCLUSIONS}

The distance education programs offered by Curtin Chemical Engineering arose from the needs of local and overseas industries, which have also supported the program from its inception. The programs have been tailor-made to suit the needs of not only industrial employees, but also mature students wishing to pursue a career in chemical engineering. In particular, our observations with respect to the use of digital technologies (online lab and virtual plant exercises) for the selected units have demonstrated that the attainment of student learning outcomes, which are in line with graduate attributes, appears to be on par with equivalent units in the undergraduate programs. In general, the distance learning students perform as well as their traditionally-taught, oncampus, postgraduate counterparts.

The introduction of online tasks in the form of lab exercises and plant tours have enabled DE students to visualise and become familiar with unit operations of chemical engineering, and have assisted in bridging the gap between traditional and distance mode students in terms of learning experiences. A thoroughly-tested prototype environment for offering online laboratory tasks to remote learners demonstrated the significance in terms of achieving learning outcomes as well as the application of digital technologies to provide experimental resources for remote students. The opinions collected from enrolled students and their managers revealed that the programs are structured at the right pace and benefit them in getting the best from their employees due to a better understanding of chemical engineering. These developments are expected to pave the way for not only gaining recognition through accreditation bodies (Engineers Australia and IChemE), but also gaining momentum in the coming years as DE programs become the most sought-after mode of education.

\section{ETHICS APPROVAL}

This study has been approved under Curtin University's process for low-risk studies (Approval number RD-6512).

\section{ACKNOWLEDGMENT}

The authors acknowledge Alcoa World Alumina Ltd. for its financial support and for helping us to establish the distance education programs in Chemical Engineering at Curtin University. 


\section{REFERENCES}

[1] D. R. Garrison and D. Shale, "Mapping the boundaries of distance education: Problems in defining the field", Am. J. Distance Educ., vol. 1, pp. 7-13, 1987.

[2] D. A. Patterson, "Impact of a multimedia laboratory manual: Investigating the influence of student learning styles on laboratory preparation and performance over one semester", Educ. Chem. Eng., vol. 6, pp. e10-e30, January 2011.

[3] L. Domingues, I. Rocha, F. Dourado, M. Alves, E. C. Ferreira, "Virtual laboratories in (bio)chemical engineering education", Educ. Chem. Eng., vol. 5, pp. e22-e27, May 2010.

[4] A. Selmer, M. Kraft, R. Moros and C. K. Colton, "Weblabs in chemical engineering education", Educ. Chem. Eng., vol. 2, pp. 38-45, 2007.

[5] J. M. Brault, P. Medellin Milán, M. Picón-Núñez, M. El-Halwagi, J. Heitmann, J. Thibault and P. Stuart, "Web-based teaching of open-ended multidisciplinary engineering design problems", Educ. Chem. Eng., vol. 2, pp. 1-13, 2007.

[6] B. Gauss, L. Jiménez, L. Urbas, C. Hausmanns and G. Wozny, "Elearning in process and chemical engineering - Trends and challenges" in Proceedings-IEEE International Conference on Advanced Learning Technologies (ICALT'04), Kinshuk, C.-K. Looi, E. Sutinen, D. Sampson, I. Aedo, L. Uden and E. Kähkönen, Eds. Los Alamitos, CA: IEEE, 2004, pp. 872-873.

[7] J. Bourne, D. Harris and F. Mayadas, "Online engineering education: Learning anywhere, anytime", J. Eng. Educ., vol. 94, pp. 131-146, January 2005.

[8] B. S. Heck, S. E. Poindexter and R. C. Garcia, "Integrating the Web into traditional teaching methods" in Proceedings of the 2000 American Control Conference, vol. 5, Evanston, IL: American Automatic Control Council, 2000, pp. 3444-3448.

[9] D. R. Garrison and D. Shale, Eds. Education at a Distance: From Issues to Practice, Malabar, FL: Krieger, 1990.

[10] M. Khalifa and R. Lam, "Web-based learning: Effects on learning process and outcome", IEEE Trans. Educ., vol. 45, pp. 350-356, November 2002.

[11] I. Masiello, R. Ramberg and K. Lonka, "Attitudes to the application of a Web-based learning system in a microbiology course", Comput. Educ., vol. 45, pp. 171-185, September 2005.

[12] P. R. Backer, "A shift in teaching methodology: From instructor led to student driven multimedia instruction" in Proceedings of the 2005 American Society for Engineering Education Annual Conference and Exposition: The Changing Landscape of Engineering and Technology Education in a Global World, Washington, DC: ASEE, 2005, pp. 12705-12721.

[13] G. Wozny, C. Hausmanns, L. Urbas and B. Gauss, "The EuPaCE.net guidelines for e-learning in process and chemical engineering" in Proceedings of PRES'05: $8^{\text {th }}$ Conference on Process Integration, Modelling and Optimisation for Energy Saving and Pollution Reduction, vol. 2, J. Klemeš, Ed. Milan: AIDIC, the Italian Association of Chemical Engineering, 2005, pp. 419-424.

[14] I. E. Allen and J. Seaman, Entering the Mainstream: The Quality and Extent of Online Education in the United States, 2003 and 2004, Needham, MA: The Sloan Consortium, 2004.

[15] W. Ibrahim and R. Morsi, "Online engineering education: A comprehensive review" in Proceedings of the 2005 American Society for Engineering Education Annual Conference and Exposition: The Changing Landscape of Engineering and Technology Education in a Global World, Washington, DC: ASEE, 2005, pp. 10991-11000.

[16] B-Learn Project. (2005, 5 May). B-Learn - Assisting teachers of traditional universities in designing blended learning. WP1 Collection of best practice cases. [Online]. Available: http://www.ut.ee/blearn/orb.aw/class=file/action=preview/id=2704 89/wp1deliverable1.pdf.

[17] H. B. Vuthaluru, H. M. Ang and B. Lynch, "Using Web-based tools for chemical engineering education: The creation of an asynchronous environment and student response to WebCT" in Chemeca 2003: Products and Processes for the 21 Century: Proceedings of the $31^{\text {st }}$ Australasian Chemical Engineering Conference, Q. D. Nguyen, Ed. Adelaide, SA: Institution of Engineers, Australia, 2003, pp. 455-463.
[18] Institution of Chemical Engineers, Accreditation of Chemical Engineering Degrees: A Guide for University Departments and Assessors. Rugby, UK: IChemE, 2012.

[19] E. Lindsay and B. Stumpers, "Remote laboratories: Enhancing accredited engineering degree programs" in Proceedings of the $22^{\text {nd }}$ Annual Conference for the Australasian Association for Engineering Education, Y. M. Al-Abdeli and E. Lindsay, Eds. Barton, ACT: Engineers Australia, 2011, pp. 588-593.

[20] E. D. Lindsay and M. C. Good, "Effects of laboratory access modes upon learning outcomes", IEEE Trans. Educ., vol. 48, pp. 619-631, November 2005.

[21] D. Lowe, C. Berry, S. Murray and E. Lindsay, "Adapting a remote laboratory architecture to support collaboration and supervision" in Proceedings of the $6^{\text {th }}$ International Conference on Remote Engineering and Virtual Instrumentation, N. Gupta and J. Pallis, Eds. Vienna: International Association of Online Engineering, 2009, pp. 103-108.

[22] D. Lowe, S. Murray, E. Lindsay and D. Liu, "Evolving remote laboratory architectures to leverage emerging Internet technologies", IEEE Trans. Learn. Technol., vol. 2, pp. 289-294, October-December 2009.

[23] C. Bright, E. Lindsay, D. Lowe, S. Murray and D. Liu, "Factors that impact learning outcomes in remote laboratories" in Proceedings of ED-MEDIA 2008: World Conference on Educational Multimedia, Hypermedia and Telecommunications, J. Luca and E. R. Weippl, Eds. Charlottesville, VA: AACE, 2008, pp. 6251-6258.

[24] D. Shallcross, N. Maynard and J. Dalvean, The Engineering Design Journey - Needs, Concept and Reality: Final Report 2011, Sydney: Office for Learning and Teaching, 2011.

[25] B. Alhalabi, M. K. Hamza, S. Hsu and N. Romance, "Virtual laboratories vs. remote laboratories: Between myth and reality" in Proceedings of Florida Higher Education Consortium $7^{\text {th }}$ Statewide Conference: Enhancing Teaching and Learning in Mathematics \& Science, 1998.

[26] I. Cameron, C. Crosthwaite, C. Norton, N. Balliu, M. Tade, A Hoadley, D. Shallcross and G. Barton, "Development and deployment of a library of industrially focused advanced immersive VR learning environments", Adv. Eng. Educ., vol. 1, pp. 1-34, Summer 2008 . 